\title{
Modernization, Science and Engineering in the Early Nineteenth Century Ottoman Empire
}

\section{Berrak Burçak}

To cite this article: Berrak Burçak (2008) Modernization, Science and Engineering in the Early Nineteenth Century Ottoman Empire, Middle Eastern Studies, 44:1, 69-83, DOI: 10.1080/00263200701711861

To link to this article: https://doi.org/10.1080/00263200701711861

册 Published online: 05 Jun 2008.

Submit your article to this journal

Џlll Article views: 557

Citing articles: 3 View citing articles $\widetilde{ }$ 


\title{
Modernization, Science and Engineering in the Early Nineteenth Century Ottoman Empire
}

\author{
BERRAK BURÇAK
}

The process of Ottoman modernization is a complex phenomenon, and to this day it has not yet been adequately treated. ${ }^{1}$ It may be stated, however, that it was primarily concerned with the notion of rescuing the empire from its defective condition by remedying its ills and directing it towards a better future. ${ }^{2}$ This brought with it the notion of progress. A belief in the powers of modern science constituted the key element; modern science was to serve as the vehicle that would carry the empire toward a much-desired, better future. ${ }^{3}$

This article argues that a scientistic mentality was prominent in the process of Ottoman modernization. Scientism here refers to a utilitarian approach to science, i.e. the acknowledgement of and pursuit of science as a useful and applicable category of knowledge, and a strong belief in the authority of science as a modernizing force to bring about the salvation of the empire. This study will illustrate the early glimmerings of that scientistic mentality. It examines the formation of this attitude through the example of one of the first Ottoman engineers, Seyyid Mustafa, who was writing in the first half of the nineteenth century. Mustafa's work sheds light on various important themes. He touches upon the themes of knowledge and learning, the transformation that these were undergoing at the time, a change which Mustafa believed paved the way to the formation of new categories of people related to the possession or the lack of information that he deemed was important and necessary, the struggle between two education systems, one traditional and the other modern, a scientistic opposed to a scientific mentality and the roots of the age-old science versus religion controversy prevalent in Turkish historiography. It is important to note, however, that modern science did not always represent one and the same thing through the Ottoman modernization period; it changed over time. For that reason, different meanings were attributed to it during the Tanzimat (1839-76), the Hamidian (1876-1908), and the Young Turk eras (1908-18), culminating in its dogmatic positivistic character during the early Republican period with Mustafa Kemal Atatürk, the founder of the Turkish Republic.

To remember what we presently know about this process, it is probably best to start with the fact that the waning of Ottoman military and political power starting in the seventeenth century gave rise to a mindset during the next century that viewed 
modern science as a tool for resuscitating an outdated military. Ottoman statesmen, guided by motives of survival, began to look toward the West for guidance in military technology, which they believed was the force behind Western strength. Thus the initial encounter between the Ottoman Empire and modern Western science was in the military field. The Ottoman state pursued the following trajectory: first, it launched new educational institutions, the Ottoman engineering schools, which offered a scientific technical education and were founded in the Ottoman capital at the end of the eighteenth century; ${ }^{4}$ second, it hired foreign experts in the form of teachers, military experts, and technicians, who came primarily from France; and, third, it promoted a linguistic shift from Eastern languages such as Arabic and Persian to European languages, mainly French during this period, in order to facilitate the acquisition of scientific and technical knowledge. All the attempts led to the formation of a new Ottoman intelligentsia, a scientific-technical elite, who, having completed their training, assisted the Ottoman sultan in his military reform project.

The new Ottoman educational institutions, first the Hendesehane and later the Mühendishâne, modelled after the French system in the eighteenth century, introduced, for the first time, modern Western science into the Ottoman Empire. Although this first attempt at a modern Ottoman education was of a purely military nature, it was nevertheless instrumental in the shaping of a new category of intellectual: the Ottoman engineer. Besides playing a role in the development of the infrastructure of the Ottoman Empire, the Ottoman engineer, as a result of his scientific and technical education, also engendered a new mode of thinking, with a certain attitude to science. If science for the Ottoman engineer represented a privileged and powerful kind of knowledge that one could possess, it also became a point of demarcation between being 'modern' and being 'backward'.

The world of the Ottoman engineer was a world imbued with a scientistic attitude manifested by a genuine enthusiasm for the use of science along with an absolute belief in its powers as a modernizing force. This force, identified on the part of the Ottoman engineer as the quintessential element of a new world order, was regarded as capable of bringing about all the desired changes necessary for Ottoman military recovery. Thanks to science, the engineer believed, the Ottoman Empire would be able to join the efforts of non-Western states to access the military strength that science had already given the West.

The earliest example of a scientistic attitude can be observed in the writing of one of the first Ottoman engineers, 'Küçük' Seyyid Mustafa, who wrote a treatise in French $^{5}$ - hereafter to be referred to as the Diatribe. Kemal Beydilli has published the text in an article entitled, 'Illk Mühendislerimizden Seyyid Mustafa ve NizâmCedîd'e Dair Risâlesi' (One of Our First Engineers Seyyid Mustafa and his Treatise on the Nizam-l Cedid). ${ }^{6}$ Far from reproducing Beydilli's work, which summarizes the text itself with biographical information about Seyyid Mustafa, this article aims to bring about a new interpretation of the text itself by placing it within a scientistic argument. Published in 1803 at the publishing house in Üsküdar established by Sultan Selim III, the work effectively combines personal history with the history of the empire. It consists of two parts: an introduction including autobiographical information, and a main part, in which Seyyid Mustafa elaborates on the scientific progress which gave way to the Nizam-l Cedid itself. 
In the Diatribe's introduction Seyyid Mustafa states that he composed the work with a twofold purpose in mind. On the one hand, he says he wrote it to thank the masters from whose works he had benefited and on the other hand, 'to talk about the initial position of the military arts and engineering in the Ottoman domains and of the fortunate revolution that they had undergone in a short amount of time'.

Seyyid Mustafa's work is a treatise clearly written as a tribute to the Nizam-l Cedid (New Order), the reform program as well as the name of the new army launched by Sultan Selim III (1789-1807). ${ }^{8}$ In fact, throughout his work Seyyid Mustafa refers to this sultan as 'our auspicious ruler' (Notre auguste souverain), both a cliché and a true expression of his feelings. The Diatribe is composed in French addressing both a foreign audience and the cultivated Ottoman elite of the time. Because the Ottomans modeled their own armed forces after those of the French and were assisted by experts coming from France, Mustafa therefore flatters the French by writing in their language so as to pay tribute to their help as well as to their success. As such, his Diatribe is a work addressed by one member of the elite to others. According to Kahraman Şakul, who wrote an appraisal on an earlier work of mine on the same subject, the Diatribe was written as Ottoman state propaganda aimed at a foreign audience. ${ }^{9}$ Furthermore, the Diatribe reveals that Mustafa is very proud to be a part of the reform project. He regards himself as a member of the new elite, in the vanguard of Ottoman modernization. It is also important to bear in mind however, that the Nizam-l Cedid was a reform program born out of serious Ottoman concerns that the formerly powerful Empire was falling behind the European states and that immediate action had to be undertaken to insure its survival. The Diatribe is therefore the culmination of such apprehension and may also be regarded as a criticism against the state of affairs before the Nizam- $\iota$ Cedid. Şakul, who sees these points as problematic, argues that the Diatribe was not written with the purpose of criticizing the old order and believes that Mustafa wrote this treatise with the outlook of a ceditci (reformist/modernist) just like many other treatise writers during his time and not that of an engineer dedicated to salvaging the state and society based on his intellectual identity. ${ }^{10}$ As I will argue in the following pages, however, these two categories, namely ceditci and engineer, are not necessarily two mutually exclusive categories.

Seyyid Mustafa was among the first group of students who were trained in the new Ottoman educational institutions during the reign of Sultan Selim III. As mentioned earlier, Beydilli in his article, in addition to the text, has also included biographical information about Seyyid Mustafa based on archival evidence. A note on the nickname Küçük, which literally means small, but stands for the younger in this context, is in order here. It was Kemal Beydilli who gave this nickname to Seyyid Mustafa in order to distinguish him from another student of the same name, whom Beydilli called Büyük (the older) Seyyid Mustafa.

'Küçük' Seyyid Mustafa was born in Istanbul in $1774 .{ }^{11}$ His father was Ahmed

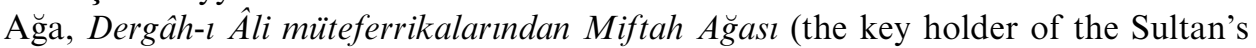
household), ${ }^{12}$ who had died when Mustafa was 11 years old. ${ }^{13}$ Towards the age of 20, Seyyid Mustafa wished to pursue an education in France, but nevertheless decided to stay in Istanbul upon hearing that Sultan Selim III was building a school 
of engineering (Mühendishâne), in the district of Südlüce near the Tersâne-i Âmire (Imperial Maritime Arsenal). ${ }^{14}$ Although there is no mention of the French Revolution in the Diatribe, Seyyid Mustafa must surely have been aware of this event, which had taken place five years earlier. He applied by petition to the Sultan to become a student at the newly established Mühendishâne. He was accepted and entered the institution in 1794 as a student with a stipend, ${ }^{15}$ and after graduating became an instructor of mathematics there. When he signed the Diatribe's introduction he did so as 'Mustafa, engineer and instructor of mathematics at the Mühendishâne in Südlüce'. ${ }^{16}$

If knowledge of Seyyid Mustafa's life is limited, his character is nevertheless clearly revealed throughout his work. The Diatribe, when taken as a memoir written by an Ottoman engineer at the beginning of the nineteenth century, provides significant information on the initial Ottoman understanding of modern Western science as perceived by one of the earliest Ottoman modernizers. Seyyid Mustafa's childlike enthusiasm for science as a modernizing force, along with his pride of being among the 'learned' in the midst of 'ignorance' offer valuable insight into the mentality of the period.

The first and the most striking aspect concerning Seyyid Mustafa is his belief that the tendency to study science is an innate characteristic as opposed to an acquired one. Seyyid Mustafa recounts in the Diatribe's introduction how he had a proclivity for the study of science from a very early age: 'I have ever since my infancy had an inclination toward the study of the sciences and the arts'. ${ }^{17}$ This may not seem to be an unusual feature. After all, many people writing their memoirs mention such tendencies. It is nevertheless important because Mustafa's description of science as an intrinsic quality goes to the heart of an Ottoman attitude to science. What is more, Seyyid Mustafa is very proud to announce that, 'raised among parents who were deprived of any mathematical knowledge', ${ }^{18}$ his must have been an innate characteristic. To substantiate his claims Seyyid Mustafa reveals how he would play as a child, drawing geometrical figures on the ground, which he would then try to explain to the other children. He also provides a vivid account of his joy upon making a compass out of two sticks and a piece of string, as well as recounting how he would observe the moon with his father's binoculars and explain to his friends that the moon was spherical in shape.

Given his belief that an understanding of science is an intrinsic quality, Seyyid Mustafa speaks out against those philosophers who deny the innate characteristic in man toward the study of science and state that it can only be an acquired characteristic. Alluding to his own natural affinity for science, Mustafa affirms:

After this premature taste, so to speak, which I observed in myself, I would very much be tempted to speak out against those philosophers who refuse to admit innate inclinations in man: this group of philosophers, numerous and brilliant, base themselves in reality on a solid ground refusing in man a certain innate taste for certain things. Science can only be an accessorial quality in man, that is to say, it can only be acquired. Pascal, the famous Pascal, can he not be used as an example? How was he able to produce at a young age, without a guiding hand, the solution of the thirty-two propositions of Euclid, by different methods? ${ }^{19}$ 
For Seyyid Mustafa, what he sees as his natural tendency toward the study of science becomes a way of setting himself apart from the rest of the world. He sees himself as a chosen individual, related to the fact that he possesses a natural tendency toward the acquisition of a certain type of knowledge. The fact that Seyyid Mustafa tells us that he is the one who explains various scientific concepts to his friends and not vice versa is a clear manifestation that he considers himself to be different from his friends because of this exclusive quality. And it is precisely this feature that distinguishes him from the other children, who are ignorant of scientific matters and who are thus clearly in need of being informed by 'naturally inclined' people such as Mustafa himself.

Seyyid Mustafa further reveals to us that his fondness for geometry continued beyond his childhood: geometrical instruments fascinated him. He claims to have read the Arabic translation of Euclid (most probably Euclid's Elements) and other such works. He also states that he learned logarithms from Gelenbevî İsmail Efendi, who himself is stated as having learned it from a Greek.

Upon seeing that the science he was interested in came from Europe, Seyyid Mustafa set out to teach himself French, which he described as 'the most universal language'. ${ }^{20}$ The new understanding of Western science as a modern category of knowledge also led to the shift in which languages such as French were coming to take the place of Arabic and Persian as the language of culture and education in the Ottoman realm.

After learning French, he read the works of such authors as Wollf, Ozanam and Bellidor. Beyond mentioning their names, Seyyid Mustafa does not give any indication as to who these authors might be. The first author Seyyid Mustafa mentions is most probably the philosopher, mathematician and scientist Johann Christian Wollf (1679-1754) - also spelled Wolf - who is best known as the German spokesman of the Enlightenment. Wollf, a student of the philosopher and mathematician Gottfried Wilhelm Leibniz, was educated at the universities of Breslau, Jena, and Leipzig, and later became an adviser on science to the Russian tsar Peter the Great (1716-25), during which time he helped found the St Petersburg Academy of Sciences. In a series of essays, all under the title Vernünftige Gedanken (Rational Ideas), Wolff emphasized that every occurrence must have an adequate reason for happening or there arises the impossible alternative that something might come out of nothing.

The second author Seyyid Mustafa talks about could well be the French mathematician Jacques Ozanam (1640-1717), who at the age of 15 produced a mathematical treatise. In 1670, Ozanam published trigonometric and logarithmic tables more accurate than the then existing ones of Ulacq, Pitiscus, and Briggs. His mathematical publications were numerous and well received.

The third author Seyyid Mustafa mentions is most probably the French military and civil engineer Bernard Forest de Bellidor (1698-1761), who after serving as professor of artillery at the French military school at La Fère, eventually rose to become inspector of artillery. Belidor wrote several notable books on engineering, artillery, ballistics, and fortifications, but his fame rests primarily on Architecture hydraulique, a work in four volumes (published in Paris in 1737-53), covering engineering mechanics, mills and waterwheels, pumps, harbours and sea works. As Seyyid Mustafa wrote the Diatribe after becoming an engineer, Bellidor's work must 


\section{B. Burçak}

have been part of either his coursework or his teaching. What is clear from his selection of authors is that Seyyid Mustafa focused on the works not of pure scientists, but rather men of science who emphasized the applied aspect of science, which was also very common among Ottoman intellectuals even of the later parts of the nineteenth century.

Seyyid Mustafa's work primarily brings out the themes of knowledge and learning. He acknowledges modern science, which he described himself as being 'devoted to', ${ }^{21}$ as a new and useful category of knowledge, especially in his assessment of Western military superiority:

There was a booming revolution in the military arts; all the European nations tried to surpass one another; there was the invention of all kinds of machines; the correction and the perfection of weaponry, and all sorts of means of attack and defense were carried out with the utmost energy. Finally, military engineering showed the benefit of all mathematical knowledge in order to declare the value of the compass in the midst of blood and fire. ${ }^{22}$

Even as an adult Seyyid Mustafa maintained the sense of superiority displayed in his early childhood. In addition to his childhood reminiscences, another instance where Mustafa displays the 'us versus them' attitude is his description of how the common people in Istanbul reacted to the engineering students' fieldwork in geometry, which took place in Okmeydanı and Kağıthane. This is how Seyyid Mustafa describes the experience:

We started studying for the first time in public in the presence of the majority of people, who are totally devoid of the sciences; the sound of ignorance rose from every corner and we were molested by it: 'Why do you draw these lines on these papers, what is their use? Warfare cannot be conducted with ruler and compass' and other accusations of the like; we spent days afflicted by exorbitant ignorance and by such conduct that was bereft of the embellishment of science. $^{23}$

This passage clearly reveals that Seyyid Mustafa considered himself, along with the other engineering students, as a select group blessed with a special, new kind of knowledge. This demonstrates the role science played in identity formation and shows how Mustafa divided the world into two different and separate spheres of existence.

For Seyyid Mustafa science, besides denoting a new and different type of knowledge, also becomes a criterion of learning, if not a value judgement. According to him, the possession or the lack of science constitutes a major demarcation point. In view of that, Seyyid Mustafa's dichotomy becomes one of erudition: a division between the 'educated' and the 'ignorant'. In the engineers' opinion, those who have received an education, like the one he received, which is a particular kind of education, are deemed 'educated'. These are sophisticated and superior people. The 'ignorant', however, for Seyyid Mustafa, are constituted by all those other people who lack such an education, are oblivious, and are thus considered second-rate. It is clear that Seyyid Mustafa believes himself to be, along with the other engineering students, 'the new man of knowledge'. These two separate categories of people 
cannot possibly be a part of the same world and undoubtedly belong to two different and separate spheres.

Seyyid Mustafa's dichotomy between the 'educated' and the 'ignorant' goes beyond just an intellectual configuration, however. The two terms Seyyid Mustafa uses to denote two different categories of people are heavily laden terms that stretch beyond a simple use of jargon. In the process of the formation of the "new man of knowledge' in the Ottoman realm science was still at this time limited to the military cadre. This dichotomy becomes very much a conflict between traditional and new ways of learning. Within the period's outlook, the 'new Ottoman man of knowledge' was someone who possessed modern science and was versed in a Western foreign language - which meant French during this period - but who did not oppose traditional knowledge. Before the eighteenth century, religious schools constituted the bulk of Ottoman education: the Quran schools (sibyan mektebi) at the elementary level, the medreses at higher level for the Muslim Ottoman subjects, and only a few educational institutions with more secular characteristics such as the Court School at the Topkapı Palace (Enderûn Mektebi) or the government bureaus that trained novices (Acemi Ŏglanları Mektebi) in the art of literary style (kitâbet). ${ }^{24}$

In the pre-modern Ottoman-Islamic school system the students received basic religious knowledge. The next stage, the medreses, would strengthen this religious knowledge. Those who sought to acquire practical and worldly knowledge, however, either had to educate themselves and/or participate in circles of cultivated men. In this respect, religious agencies were responsible for providing education for ordinary people. $^{25}$ Accordingly, the ulema were in charge of almost all education. The emergence of a secular education thus jeopardized their status.

These two terms come to represent two opposite sides in a power struggle, a conflict between traditional versus modern education within the Ottoman Empire. What is more, Mustafa's dichotomy is set in a context where it plays a significant role in identity formation. In his eyes, the 'educated' are the 'modern' elite who constitute a minority with a mission to resuscitate Ottoman military strength and the educated are superior to those who are traditional.

According to Seyyid Mustafa, the 'educated', who in that period were still limited to engineers, were the precursors of modernization and of progress. Thanks to his scientific and technical education Seyyid Mustafa, as the engineer, saw himself as the distinct agent of Ottoman modernization. He firmly believed that engineers like him were to play a crucial part in the making of a modern world - a world enlightened and guided by science.

Seyyid Mustafa's world was one where engineers possessed the power to design and create; Ottoman engineers were actively involved in the military reform project. He narrates how 'in order to show to all classes of men the great advantage of mathematics applied to the art of war and to fortification', ${ }^{26}$ Sultan Selim III had the engineering students, including Seyyid Mustafa, build military barracks in various places in Istanbul such as Mirahur Köşkü, Okmeydanı and Levent Çifliği. Seyyid Mustafa states that these buildings, when displayed to the people of Istanbul, 'attracted a significant crowd of the inhabitants of Constantinople'. ${ }^{27}$

It is clear from Seyyid Mustafa's account that these edifices, standing as solid artefacts, represented the concrete symbols of a new age. These buildings worked to show all those 'ignorant' people, who were perplexed as to what science was actually 
good for, the uses of modern science and technology. This was indeed the representation of science as useful knowledge. This endeavour aimed to convince the masses of the indispensable character of Ottoman reform and to validate it in their eyes. Accordingly, modernization also affected the Ottoman urban landscape. As Hakan Kaynar rightly pointed out, it was going through a major transformation: 'From now onward, magnificent buildings were no longer mosques, but military barracks. Not only in the capital, but also in the provinces, military barracks became the fundamental buildings. ${ }^{28}$

For Seyyid Mustafa, science and technology, those innovative entities with tremendous restorative powers, constituted the quintessential features of this new world which was beginning to appear. Thinking as he does, it was only natural for Seyyid Mustafa to consider all those who were lacking of his education and knowledge to be ignorant and vulgar. Seyyid Mustafa regarded such people with scorn, and avoided their company. It ought to be noted, however, that Seyyid Mustafa's dichotomy was between the 'educated' and the 'ignorant', and not between man of science and the 'religious fanatic'. For Seyyid Mustafa the 'ignorant' were backward, lethargic and old-fashioned, and thus useless, if not harmful; and the 'educated' are regarded as modern, vibrant and progressive, therefore useful and constructive.

In view of this perception, the Diatribe also attests to a new relationship between modern science and loyalty to the Ottoman sultan, by serving his modernization project. This worked in a double fashion. The Ottoman state opened military schools to create "scientific officers ${ }^{29}$ that it wished to use in implementing military reform. Once their training was completed, the state utilized these engineers in various reform projects such as the building of forts. In this respect, their education was not only one that was centered on the acquisition of scientific and technological knowledge, but it also engendered a world-view that was based on the Ottoman Sultan and the desire to serve him in the best manner possible. Therefore, the Ottoman engineer's validation came through his abilities, his loyalty to the Sultan and the desire to serve him. This is the very reason why Seyyid Mustafa laid such a great emphasis on being 'educated', because his own position depended on his education and his function as a reformer.

The Diatribe also attests to the difference between a scientific approach (i.e., an understanding of science as a pure scientific pursuit based on observation and experimentation of which the end result would be production of scientific knowledge) and a scientistic approach (i.e., an understanding of science based on the acquisition of scientific knowledge). Seyyid Mustafa communicates a certain feeling of dissatisfaction he felt from his readings. When enumerating the various authors he read, he had affirmed that 'these classical authors did not fulfill my aim, which was to apply mathematics to military tactics, fortification and mechanics as well as the acquisition of a certain degree of perfection capable of procuring the handling of these sciences in all the branches of mechanics from which they are derived' ${ }^{30}$ This is a utilitarian approach to science, which focused on its instrumentality rather than on its pure scientific aspect.

Seyyid Mustafa states that Pascal owed his fame and importance to the fact that he was a man of science and produced scientific knowledge. That is why Pascal was 
remembered and was also deemed superior by Seyyid Mustafa. The latter, however, although he himself was aware of the importance of the production of scientific knowledge, does not seem to be troubled with this aspect of science concerning himself. He seems to be content with the mere acquisition and application of scientific knowledge, not its production.

Although this approach on the part of the Ottoman engineer may not have been a scientific one per se, he was nevertheless very much aware of the fact that science constituted a powerful tool for the advancement and well-being of a nation in modern times. For this reason, Mustafa tried to incorporate the Ottoman Empire into what he saw as a global phenomenon. In view of this, Mustafa promotes science not as the product of one culture but as a universal phenomenon to which various cultures could contribute.

Seyyid Mustafa also touched upon the themes of mutability and progress in their relationship to science. He described how nations and people change all the time along with their basic institutions. The sciences and the arts travelled around the world where they chose to settle down in a specific place during a specific time period. Seyyid Mustafa's Zeitgeist is without doubt a progressive one, which is cultivated by the sciences and the arts:

The passing of centuries and the continuous change of time[s] modifies and shapes differently this great manufacture of the universe, as well as the little workshop of man. Nations and men change, and the fundamental institutions of states diversify infinitely; the sciences and the arts go round the world; and knowledge follows and obeys those who cultivate and honor it, as if the sciences and the arts choose [time and again] a central [rallying] point. There is plenty of evidence for what we are arguing. History, however, provides us with a rather sharp example in this matter. It is said, according to the French chronicles that Haroun al-Rashid gave a clock to Charlemagne, King of France and the first emperor of the Occident, and this was the first time that such an artifact appeared in Europe. ${ }^{31}$

The place of esteem held by the sciences and the arts in Seyyid Mustafa's eyes is evident from the above quotation. He attributes great historical agency to them. He regards the sciences and the arts as two distinguished entities with immense powers. According to him the sciences and the arts are responsible for providing prestige and power to a people and elevating them to the status of a civilization. Only those people who appreciate the value of the sciences and the arts and consequently promote them can thrive and become prosperous. The fact that Seyyid Mustafa mentions the clock given to Charlemagne by Harun al-Reşid, the fifth caliph of the Abbasid dynasty, is to highlight the fact that the Muslim lands were at some point very powerful and prosperous, at a time when the West was not so prosperous. For Seyyid Mustafa, science constituted the building block of civilization.

By acknowledging the fact that the centre of civilization was not a fixed spot in either time or space, but rather a variable occurrence, Seyyid Mustafa points to the universal nature of civilization. And given its universal nature, science for him became an activity that was not solely exercised by one civilization, nor was it the 
product of only one civilization. This was a universal phenomenon, in which many different cultures might play a significant part.

Seyyid Mustafa also recognized that times had changed and that there was a new order, which he himself saw as based on the appreciation and the cultivation of modern science. At this specific point in time, the centre of civilization was the West. What Seyyid Mustafa was trying to do is to bring the Ottoman Empire into this new system. In this respect, science was not an exclusive phenomenon.

What is more, the Diatribe also sheds light on the so-called science versus religion controversy. Seyyid Mustafa alluded to a conflict between those who professed the virtues of traditional education and those others who were for modern education. With the opening of military schools in the Ottoman capital, education within the Ottoman Empire started to shift from the Islamic tradition to the Western tradition. As mentioned earlier, the ulema were in charge of education before modern education was launched. The conflict between the two types of education has more often been conceived of as a conflict between religion and science and has left its imprint in later Turkish historiography as such. It can be said that a 'science versus religion controversy' was not really relevant for the period and that it rather took the form of modernism vs. tradition, and was, in the end, a conflict of interest rather than a conflict of doctrine.

Seyyid Mustafa also touched upon the then state of Ottoman affairs. He recounted that the Ottomans before the era of modern warfare were militarily successful because they relied mainly on their courage and physical capabilities. Yet he also added that when significant transformation relating to science and military technology took place in Europe, the Ottomans, who "were swollen with pride due to their former military victories', ${ }^{32}$ were unfortunately not able to grasp the necessities of modern warfare and believed that they could fight the modern European armies with their traditional techniques. Cultivating this belief they grew complacent and did not attach any importance to the new military arts which they deemed to be only a 'child's game'. Mustafa points out that some people tried to benefit from this situation:

The class of idiots and superstitious, from whom no nation can more or less be exempt, profited from this situation, and tried to convince the simple minded that the imitation and assimilation of other people could only be a crime. They armed the simple minded against the higher-elevated minds who aspired to reform. Accordingly, these unhappy souls tried to convince the majority of the people that to fight the enemy with the same weapons constituted a crime for a Muslims. $^{33}$

Mustafa also talked about resistance to reforms and commented on the way in which Sultan Selim III dealt with this problem:

A host of misled critics, sometimes pushed by haste, sometimes by malevolence or self-interest, murmured and created thousands of obstacles. They stopped talking due to the sovereign's fervor and the zeal of the people he employed, because none of this seemed to affect him. His career as the restorer of his Empire was set and he followed it in cold blood, which is a characteristic of 
superior people. ${ }^{34} \ldots$ He showed that he was above such mediocre considerations. It is in this fashion that he silenced the mouth of the ignorant. ${ }^{35}$

We can see that while the first quotation brings to light ideas, the second one talks about actions. These are very important words indeed, because they not only provide a significant vantage point from which to look at the relationship between science and religion in the Ottoman Empire, but also offer an insight into the omnipresent 'science versus religion' antagonism in modern Turkish historiography. Here we can find the roots of a modern debate.

The first quotation reveals that Seyyid Mustafa did not in any instance openly pronounce that religion stood against science. He acknowledges, however, that there was resistance to military reform among certain people, a group whom he refers to as a 'class of idiots and superstitious'. These people, by the use of a religious discourse, tried to capitalize on the authority of religion in order to render their arguments more persuasive. What Seyyid Mustafa is saying is that some people, without telling us who they really are, although he is most probably alluding to some sections of the Ottoman ulema, used the principle of bidat or innovation in Islam as an influential tool in order to persuade the population to stand against reform. ${ }^{36}$

It can be said that Seyyid Mustafa felt personally attacked by criticisms of modernization because he was the product of it. The new military schools in the Ottoman capital were opened with the aim of being able to fight the enemy with his own weapons. Seyyid Mustafa was very conscious that his own standing and identity had been created within such a framework. Hence his situation became a personal issue for him. It was therefore natural for him to assume a defensive position.

While it is well known that according to a hadith (saying of the Prophet Muhammad) 'whoever imitates a people becomes one of them, ${ }^{37}$ it is also known that the Ottoman attitude to warfare proved to be an exception to this. It was agreed that to be able to fight the non-Muslim enemy it might be necessary to learn from them. As Uriel Heyd put it, 'Leading 'ulemā not only sanctioned and supported the innovations initiated by the sultans and their military and civil advisers, both Ottoman and European. Some of them also played a major role in conceiving, suggesting and planning reforms along European lines. ${ }^{38}$ Since jihad (holy war), the high ulema argued, constituted the primary duty of believers, the strengthening of the armed forces was a significant religious duty. ${ }^{39}$ Halil İnalcik also shares the same opinion: 'The Ottoman official ulema who supported the idea of reform broadened the interpretation of weaponry to include any tool or medium whose adoption would bring material benefit to and assure the continuance of the Islamic religion and Islamic community in general. ${ }^{40}$ Heyd also mentions that authority was found in the Quran, especially in such verses as 'but fight the idolators to the ends they fight you' ${ }^{41}$ and 'prepare against them what arms you can muster'. ${ }^{42}$ In this respect, the claim on the part of those who argued in favour of the above quotation that 'to fight the enemy with the same weapons constituted a sin for a Muslim' was not really relevant for the period in question. ${ }^{43}$

Nevertheless, Heyd also draws attention to the fact that not all sections of the ulema were favourable to modernization attempts within the Ottoman realm and that the attitude of the ulema who supported the reforms was not representative of the whole ulema corps. ${ }^{44}$ 
It is clear that there was resistance to modernization attempts. This state of affairs in the Ottoman Empire was, however, much more related to issues of self-interest and self-preservation on the part of the Janissaries who cooperated with some sections of the ulema than anything else. It should be noted, however, that this is not the same thing as saying that religion stood against science or that it was religious fanaticism that kept the Ottoman Empire backward. According to Akşin Somel, the ulema and the Janissaries regarded military and educational reforms as threats to their own existence and status. ${ }^{45}$

Although Somel's assessment applies to a later period, it is nevertheless useful in shedding light on the fact that a similar situation had taken place earlier. In this respect, it is clear that certain groups in the Ottoman Empire were using religion as a powerful ideological tool in order to maintain their own supremacy. It would be natural for such people, who believed that their standing was being slowly eroded over time, to be concerned about their own status and stand against the establishment of modern educational institutions in the Ottoman Empire because they feared they would lose their autonomy and authority. Therefore these people reacted, sometimes in a violent fashion. The deposition of Sultan Selim III after a Janissary revolt is a case in point.

Attempts at reform led to two separate forces in the Ottoman realm. On the one hand, there were the pro-reformists, who played a prominent role after the fall of Sultan Selim III in 1808 - as in the case of Mustafa Bayraktar, the notable of Ruscuk, Bulgaria. After a failed attempt to reinstate Selim III, Bayraktar became the vizier and purged the soldiers who had rebelled against Selim III, removed conservatives from the government and replaced them with men sympathetic to reform. On the other hand, there was another camp made up of the Janissaries and the ulema that were threatened by the effects of modernization on their own status in the empire. For this reason they reacted against military reform whenever they could. Therefore, the 'science versus religion' debate prevalent in the OttomanTurkish historiography on science may be approached in the following manner. The new intellectual, as a means of legitimizing his superiority as well as his authority, chose to label his opponents as the exact opposite of what he chose to call himself and chastised them on behalf of the new science, modernity and progress. As the vanguard of modernity, it would only be natural for such people as Seyyid Mustafa to see all those others who did not share his education or his belief in reform as backward looking people. Therefore, for the Ottoman engineers, the demarcation line was between those who possessed knowledge of science (i.e., the educated) and those who did not have knowledge of science (i.e., the ignorant). The educated, looking at the world from their patriotic-pragmatic viewpoint, believed the only way to salvage the Ottoman Empire from disintegration was through military reform. For that reason, the educated represented revitalization and advancement, while all others stood for stagnation and deterioration. The whole debate was centred on the issue of the survival of the Ottoman state. According to the Ottoman engineer, if the Ottoman Empire was ailing, then its recovery was to come through the adoption of science and technology. Although the ulema were a part of this process, there were nevertheless also segments of 
ulema which feared that their own standing was being eroded and stood against reform.

Seyyid Mustafa ended his work with the following enthusiastic and optimistic words related to Ottoman modernization and the promising future of the Ottoman state:

The amazement became so widespread that no one hesitated a single moment to think that everything was now different and that we all were, so to speak, in a new world order, in which we needed to deliver ourselves from all the prejudices of the past. As for myself, I am so delighted to see my homeland in the state that I have desired so badly, enlightened day by day by the torch of sciences and the arts, that it is no longer possible for me to remain silent. ${ }^{46}$

These words attest to a break with the past, a real hope for the future and indicate a genuine belief in modern science's restorative power. Inasmuch as modern science was invoked as a healing force, it was always within the military sphere for the resuscitation of the Ottoman state. There are no social concerns whatsoever: in no instance does Seyyid Mustafa display a desire to educate the masses, for example, or to transform the society of his time. Seyyid Mustafa's dichotomy remains very much within a highly circumscribed context where modern science was restricted to the elite. He was happy with the way things stood, because it constituted the perfect means of delineating himself from the rest of society. The initial attempts at modernization restricted to the military sphere would, however, undergo transformation during the next period and be expanded in scope to include the social arena. Modern science for the next generation of intellectuals was to become the central tenet in creating the Ottoman citizen.

\section{Notes}

1. For studies on Ottoman modernization see, R. H. Davison, Reform in the Ottoman Empire 1856-1876 (Princeton, NJ: Princeton University Press, 1963); B. Lewis, The Emergence of Modern Turkey (New York: Oxford University Press, 2002); N. Berkes, The Development of Secularism in Turkey, 2nd edn (London: Hurst \& Co., 1998); Ş. Mardin, The Genesis of Young Ottoman Thought: A Study in the Modernization of Turkish Political Idea, 2nd edn (Syracuse, N.Y.: Syracuse University Press, 2000). For a revisionist approach, see E.J. Zürcher, Turkey: A Modern History, 3rd edn (London and New York: I.B. Tauris, 2004).

2. For a recent reevaluation of reform literature of the period in question, see K. Beydilli, 'Küçük Kaynarca'dan Tanzimât'a Islâhât Düşünceleri' İlmî Araştımalar, No.8 (1999), pp. 25-64.

3. There is ample literature on science in Ottoman Turkish history. For a representative sample see, A. Adivar, La science chez les Turcs ottomans (Paris: G.-P. Maisonneuve, 1939); Transfer of Modern Science \& Technology to the Muslim World. E: İhsanoğlu (ed.) (İstanbul: IRCICA, 1992); S. H. Bolay, Türkiye'de Ruhcu ve Maddeci Görüşün Mücadelesi, $4^{\text {th }}$ edn (Ankara: Akçă̆ Yayınları, 1995); M. Akgün, Materyalizmin Türkiye’ye Girişi ve İlk Etkileri (İstanbul: İnsan Yayınları, 1986); M. Korlaelçi, Pozitivizmin Türkiye'ye Girişi ve Illk Etkileri, $2^{\text {nd }}$ edn (İstanbul; Hece Yayınları, 2002); M. Ş. Hanioğlu, The Young Turks in Opposition (New York, Oxford: Oxford University Press, 1995); M. Ş. Hanioğlu, Preparation for A Revolution: The Young Turks 1902-1908 (New York, Oxford: Oxford University Press, 2001); M. Ş. Hanioğlu, Blueprints For A Future Society: Late Ottoman Materialists on Science, Religion and Art', in E. Özdalga (ed.), Late Ottoman Society: The Intellectual Legacy (Routledge: Curzon, 2004), pp. 26-119; B. Burçak, 'Science, A Remedy for All Ills, Healing the Sick Man of Europe”: A Case for Ottoman Scientism', (Ph.D. Thesis, Princeton University, 2005).

4. On the engineering schools, see Ç. Uluçay and E. Karatekin, Yüksek Mühendis Okulu (Istanbul: Berksoy and Matbaası, 1958); K. Beydilli, Türk Bilim ve Matbaacılı Tarihinde Mühendishâne, 


\section{B. Burçak}

Mühendishâne Matbaası ve Kütüphanesi 1776-1806 (Istanbul: Eren Yayınları, 1995); M. Kaçar, 'Osmanlı Devleti’nde Bilim ve Eğitim Anlayışında Değişmeler ve Mühendishanelerin Kuruluşu' (P.D. Thesis, Istanbul University, 1996).

5. Diatribe de L'ingénieur Séid Moustapha sur l'état actuel de l'art militaire, du génie et des sciences à Constantinople (The Diatribe of Engineer Seyyid Mustafa on the Present State of the Military Arts, Engineering and Sciences in Constantinople) (İstanbul: Üsküdar Matbaası, 1803) in K. Beydilli, 'İlk Mühendislerimizden Seyyid Mustafa ve Nizâm-1 Cedîd'e Dair Risâlesi', Ístanbul Üniversitesi Edebiyat Fakültesi Tarih Enstitüsü Dergisi, No.13 (İstanbul: Edebiyat Fakültesi Basımevi, 1987), pp.387-479. See also, Sütlüce Matematik Okulu Oğretim Üyesi, Mühendis Seyyid Mustafa, Ístanbul'da Askerlik Sanat, Yeteneklerin ve Bilimlerin Durumu Üzerine Risale (İstanbul: Tüyap, 1986).

6. K. Beydilli, 'Ilk Mühendislerimizden Seyyid Mustafa ve Nizâm-1 Cedîd'e Dair Risâlesi', Ístanbul Üniversitesi Edebiyat Fakültesi Tarih Enstitüsü Dergisi, No.13 (İstanbul: Edebiyat Fakültesi Basımevi, 1987), pp. 387-479.

7. Diatribe, p. 10.

8. For a classic treatment on the Nizam-l Cedid see, S. Shaw, Between Old and New: The Ottoman Empire under Sultan Selim III, 1789-1807 (Cambridge, M.A.: Harvard University Press, 1971). See also, C.E. Bosworth, 'Nizâm-1 Djedid', EI², VIII, pp. 75-76 and V. Aksan, 'Selim III', EI', IX, pp. 132-134.

9. On his remarks on my 'Science, A Remedy for All Ills, Healing the Sick Man of Europe”, see K. Şakul, 'Nizâm-1 Cedid Düşüncesinde Batılılaşma ve İslami Modernleşme.' Dîvân: İlmî Araştırmalar no.19, $(2005 / 2)$, pp. 128-129.

10. See Şakul, “ Nizâm-1 Cedid Düşüncesinde Batılılaşma ve İslami Modernleşme.’

11. Beydilli, 'İlk Mühendislerimizden Seyyid Mustafa'.

12. The miftah ăgast, literally meaning the 'ă̆a of keys' was one of the five ăgas of the Hass Oda (Privy Chamber), and was responsible for Sultan's keys. This office was abolished in 1833. See M.Z. Pakalın, Osmanlı Tarih Deyimleri ve Terimleri Sözlüğü II (Istanbul: Milli Eğitim Basımevi, 1951).

13. Beydilli, 'İlk Mühendislerimizden Seyyid Mustafa, p.415.

14. Diatribe, p.6.

15. Ibid., p.16.

16. Ibid., p.11.

17. Ibid., p. 2 .

18. Ibid., p.3.

19. Ibid., pp.2-3.

20. Ibid., p.5.

21. Ibid., p.4.

22. Ibid., p.14.

23. Ibid., pp.6-7.

24. See S.A. Somel, The Modernization of Public Education in the Ottoman Empire, 1839-1908: Islamization, Autocracy and Discipline (Leiden, Boston and Köln: Brill, 2001).

25. Ibid., pp.18-19. For information on Quran schools and medreses see O.N. Ergin, Ístanbul Mektebleri ve İlim, Terbiye ve Sanat Müesseseleri Dolaylsiyle Türkiye Mâarif Tarih, Vol.1-2, 2nd edn (Istanbul: Eser Kültür, 1977), and C. Baltacı, 'Osmanlı Eğitim Sistemi', Yeni Türkiye, Special Issue: Eğitim, No.7 (Jan.-Feb. 1996), pp.467-70.

26. Diatribe, p.7.

27. Ibid., p.8.

28. H. Kaynar, 'Sosyal İktidar ve Şehir: 19. Yüzyıl Osmanlı Şehirlerindeki Mekansal Değişimler Üzerine', Kebikeç, No.10 (2000), p.146.

29. This term was used by Ekmeleddin İhsanoğlu.

30. Diatribe, p.4.

31. Ibid., p.12.

32. Ibid., p.15.

33. Ibid., p.16.

34. Ibid., p.18.

35. Ibid., p.20.

36. On the concept of bidat see, J. Robson, 'Bid 'a', EI ${ }^{2}, \mathrm{I}, \mathrm{p} .1199$.

37. Sunan Abu-Dawud, Vol.4 (Hums: Muhammad Ali al-Sayyid, 1969), p.44. 
38. U. Heyd, 'The Ottoman 'Ulemā and Westernization in the Time of Selīm III and Mahmūd II', Scripta Hierosolymitana, No.9 (1961), p.64.

39. Ibid., p.74.

40. H. İnalcık, 'Some Remarks on the Ottoman Turkey's Modernization Process', in İhsanoğlu (ed.), Transfer of Modern Science and Technology to the Muslim World, p.52.

41. Quran, 9:36. Translated by Ahmed Ali (Princeton, NJ: Princeton University Press, 1988).

42. Quran, 8:60.

43. Heyd, 'The Ottoman 'Ulemā', p.74.

44. Ibid., p.69.

45. Somel, The Modernization of Public Education, p.22.

46. Diatribe, p.33. 